\section{BRAZIULIAN JOURNAL}

OF MEDICAL AND BIOLOGICAL RESHARCH

www.bjournal.com.br
ISSN 0100-879X

Volume 43 (12) 1135-1244 December 2010

BIOMEDICAL SCIENCES

AND

CLINICAL INVESTIGATION

Braz J Med Biol Res, December 2010, Volume 43(12) 1167-1172

doi: 10.1590/S0100-879X2010007500138

Clinical and immunological features of patients with atopy and concomitant HTLV-1 infection

F.P. Gaspar-Sobrinho, A. Souza-Machado, S.B. Santos, G. Orge, H.A. Lessa1, A.A. Cruz and

E.M. Carvalho

The Brazilian Journal of Medical and Biological Research is partially financed by
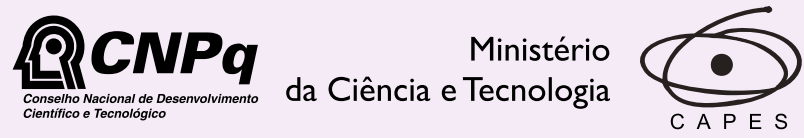

Ministério da Educação

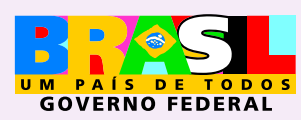

DFAPESP

Institutional Sponsors
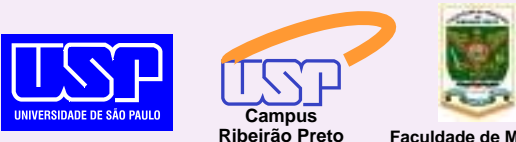

Ф SHIMADZU

GE Healthcare
Hotsite of proteomics metabolomics developped by:

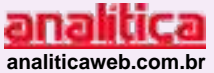

Thermo
SCIEN TIFIC 


\title{
Clinical and immunological features of patients with atopy and concomitant HTLV-1 infection
}

\author{
F.P. Gaspar-Sobrinho ${ }^{1}$, A. Souza-Machado ${ }^{2,3}$, S.B. Santos ${ }^{1}$, G. Orge ${ }^{1}$, \\ H.A. Lessa ${ }^{1}$, A.A. Cruz ${ }^{2}$ and E.M. Carvalho', \\ 1Serviço de Imunologia, Hospital Universitário Prof. Edgard Santos, \\ Universidade Federal da Bahia, Salvador, BA, Brasil \\ ${ }^{2}$ Programa para o Controle da Asma na Bahia (ProAR), Salvador, BA, Brasil \\ ${ }^{3}$ Departamento de Biomorfologia, Instituto de Ciências da Saúde, \\ Universidade Federal da Bahia, Salvador, BA, Brasil \\ ${ }^{4}$ Instituto Nacional de Ciência e Tecnologia de Doenças Tropicais, Salvador, BA, Brasil
}

\begin{abstract}
Human T-cell lymphotropic virus type 1 (HTLV-1) induces an exacerbated type 1 immune response characterized by high spontaneous IFN- $\gamma$ and TNF- $\alpha$ production. Allergic rhinitis and asthma are associated with the type 2 immune response, with elevated secretion of IL-4 and IL-5. The aim of this study was to characterize the immune response in atopic HTLV-1 carriers. The cytokine profile of atopic HTLV-1 carriers $(\mathrm{N}=10$; all females) was compared with that of non-atopic HTLV-1 carriers ( $\mathrm{N}$ $=14 ; 9$ females and 5 males). Mean patient age of atopic and non-atopic groups was $45 \pm 8$ and $38 \pm 11$ years, respectively. All atopic HTLV-1 carriers had rhinitis with or without asthma and a skin prick test positive for Dermatophagoides pteronyssinus antigen 1 (Derp-1). There was no difference in cytokine levels between the two groups in unstimulated peripheral blood mononuclear cell cultures. In cultures stimulated with Derp-1, IFN-y levels tended to be higher $(P=0.06)$ and IL-5 levels were higher $(P=0.02)$ in atopic HTLV-1 patients than in non-atopic subjects. In contrast, IL-10 was lower $(P=0.004)$ in atopic than in non-atopic HTLV-1-infected subjects. This study shows that HTLV-1 infection with an exaggerated type 1 immune response does not prevent atopy. In this case, the exacerbated type 1 and type 2 immune responses were due to a lack of IL-10 production, a cytokine that plays an important role in down-modulating type 1 and type 2 immune responses and in preventing the development of chronic inflammatory diseases.
\end{abstract}

Key words: Asthma; Atopy; Cytokines; HTLV-1; Rhinitis

\section{Introduction}

Human T-cell lymphotropic virus type 1 (HTLV-1) is a retrovirus that predominantly infects $\mathrm{CD} 4^{+}$and $\mathrm{CD} 8^{+} \mathrm{T}$ cells, inducing high spontaneous production of Th1 cytokines, including tumor necrosis factor alpha (TNF- $\alpha$ ), interferon gamma (IFN-y) and interleukin 2 (IL-2). Alarge proportion of HTLV-1-infected subjects are asymptomatic, but morbidity associated with the infection has been well documented. In addition to adult T-cell leukemia/lymphoma (ATLL) and HTLV-1-associated myelopathy/tropical spastic paraparesis (HAM/TSP), patients may present an overactive bladder, sicca syndrome, artropathy, uveitis, and periodontal disease (1-3). Additionally, HTLV-1 infection may influence the immune response to other pathogens, increasing susceptibility and modifying the clinical manifestation of strongyloidiasis $(4,5)$, tuberculosis $(6,7)$, schistosomiasis $(8)$, and scabies (9). The pathology related to HTLV-1 infection is associated with an exaggerated and inappropriately modulated immune response, and a high proviral load (10). The mechanisms related to the ability of HTLV-1 to increase susceptibility or influence the clinical course of other diseases are not fully understood. Regarding helminth infections, it is known that the defense mechanism is associated with the type 2 immune response. In patients co-infected with HTLV-1 and strongyloidiasis or HTLV-1 and schistosomiasis there is a reduction in IL-4, IL-5 and IL-13 production in cultures stimulated with parasite antigens $(11,12)$. Moreover, there is

Correspondence: E.M. Carvalho, Serviço de Imunologia, Hospital Universitário Professor Edgard Santos, Rua João das Botas, s/n, 5o andar, 40110-160 Salvador, BA, Brasil. Fax: +55-71-3245-7110. E-mail: edgar@ufba.br and imuno@ufba.br

Received April 4, 2010. Accepted October 27, 2010. Available online December 3, 2010. Published December 20, 2010. 
an inverse correlation between IFN- $\mathrm{Y}$ and IL-4, and between IFN-y and parasite-specific IgE production (13). Therefore, in such cases, it is clear that the exaggerated type $1 \mathrm{im}$ mune response observed in HTLV-1 infection decreases the helminth-driven Th2 response.

Asthma and rhinitis are common chronic allergic (atopic) diseases, and, similar to helminth infection, are associated with a strong type 2 immune response, accompanied by the production of high levels of IL-4, IL-5, IL-13, increased numbers of eosinophils, and increased IgE synthesis (14-16). We have shown previously that the prevalence of atopy and allergic diseases is lower in HTLV-1-infected subjects than in uninfected individuals (17), and that atopy and HTLV-1 infection may co-exist (18). The objective of the present study was to characterize the immune response in patients with HTLV-1 and concomitant atopy, and to determine whether HTLV-1 infection influences the immune response to Dermatophagoides pteronyssinus (Derp) antigen, the most common aeroallergen among atopic patients in Brazil.

\section{Material and Methods}

\section{Patients}

Participants were identified at the HTLV-1 Multidisciplinary Clinic of Hospital Universitário Prof. Edgard Santos (HUPES), Salvador, Bahia, Northwestern Brazil. All patients had positive serology for HTLV-1 determined by an enzyme-linked immunosorbent assay (ELISA, Cambridge Biotech Corporation, USA), and confirmed by Western blot (Genelabs, Singapore). Additionally, all sera were negative for HIV, syphilis, hepatitis B, and hepatitis C. A complete neurological exam was performed to determine the presence of mild manifestations of HTLV-1-related myelopathy and the Expanded Disability Status Scale (EDSS) was applied. A survey to evaluate the prevalence of atopy in a sample of asymptomatic HTLV-1 carriers admitted to the clinic was performed previously using a directed questionnaire on the basis of the International Study of Asthma and Allergies in Childhood (ISAAC) (19), and clinical examination (17). Based on this survey, 15 patients with atopy and 15 controls paired for age were selected to participate in the present study. However, at the scheduled appointment to have blood drawn for immunological studies, only 24 HTLV-1-infected subjects showed up for evaluation. All atopic individuals had a history of asthma or chronic rhinitis in the preceding 12 months, and had a positive skin prick test (SPT) to at least one aeroallergen. Each atopic and non-atopic recruited volunteer had at least three stool samples negative for intestinal parasites.

\section{Skin prick test}

The SPT was performed using a panel with nine relevant local allergens: $D$. pteronyssinus, D. farinae, Blomia tropicalis, Aspergillus fumigatus, Cladosporum herbarum,
Periplaneta americana, Blattella germanica, and dog and cat epithelia (AlkAbello, Denmark), according to a standardized technique (17). Histamine (1:1000) and saline were used as positive and negative controls, respectively. To avoid possible circadian differences in skin reactivity, skin tests were done between 9:00 and 11:00 am. The size of the reaction was determined by measuring the perpendicular diameters of the papule and then halving the sum [(d1 + d2) / 2]. The skin reaction was considered to be positive after 20 min when the mean diameter was $\geq 3 \mathrm{~mm}$ in the presence of a positive histamine reaction and in the absence of a reaction to saline control.

Patients taking antiallergic or immunosuppressive drugs, or with a clinical diagnosis of HAM/TSP were excluded. The study was approved by the Hospital Universitário Prof. Edgard Santos Medical Ethics Committee and all participants gave written informed consent to participate.

\section{Cell cultures}

Peripheral blood mononuclear cells (PBMC) were isolated from heparinized venous blood by density gradient centrifugation with Ficoll-Hypaque. The cells were cultured in RPMI 1640 (Life Technologies GibcoBRL, USA), 10\% human $A B$ serum (Sigma, USA), glutamine, HEPES, and antibiotics. A total of $3 \times 10^{6}$ cells $/ \mathrm{mL}$ were plated onto 24well flat-bottom culture plates (Falcon, Becton Dickinson, USA). The cell cultures were kept unstimulated (medium alone), or stimulated with $25 \mu \mathrm{g} / \mathrm{mL}$ Derp-1 (International Pharmaceutical Immunology of Brazil, Ltda., IPI-ASAC, Brazil) or phytohemagglutinin (1:10 - final dilution). Cell cultures were incubated at $37^{\circ} \mathrm{C}$ with $5 \% \mathrm{CO}_{2}$ and $95 \%$ air for $72 \mathrm{~h}$. The supernatant fluid of cell cultures was collected and stored at $-20^{\circ} \mathrm{C}$ until use.

\section{IFN-y, IL-5 and IL-10 ELISA}

ELISA sandwich techniques were used to measure cytokine levels following instructions described by the manufacturer (PharMingen, USA). Briefly, microtiter plates were coated with purified anti-human cytokines. After blockage with bovine serum albumin (BSA), culture supernatants or standards of recombinant cytokines were added. Plates were then incubated again with biotinylated mouse anti-human cytokines. Finally, streptavidin conjugated to horseradish peroxidase (Sigma) was added, followed by the substrate tetramethylbenzidine (Calbiochem, USA). Absorbance was measured at $450 \mathrm{~nm}$ using a Labsystem Multiskan ELISA reader. Data are reported as picograms per milliliter based on a standard curve generated using recombinant human cytokines.

\section{Statistical analysis}

Statistical analysis was performed using the Statistical Package for the Social Sciences (SPSS) software, version 9.0 for Windows. The Mann-Whitney U-test was used to compare the distribution of independent numerical 
variables. The level of significance was set at $P<0.05$ for all analyses.

\section{Results}

\section{Demographic and clinical data of atopic and non-atopic HTLV-1 patients}

The age, gender, clinical status, and the response to aeroallergens of the 10 patients infected with HTLV-1 and with atopy are shown in Table 1. All patients were females, and their mean age was 45 \pm 8 years. All atopic patients presented chronic rhinitis, including $3(30 \%)$ cases with concomitant asthma, and $1(10 \%)$ patient who also had eczema. All atopic patients were SPT-positive to $D$. pteronyssinus antigen (100\%), 9 patients responded to $D$. farinae $(90 \%)$, and 6 to $B$. tropicalis $(60 \%)$. Only 2 patients were positive to $B$. germanica, 1 patient to $A$. fumigatus and 1 to cat epithelium (data not shown). No patient presented cutaneous hyperreactivity to $C$. herbarum, $P$. americana or dog epithelium antigen. The control group had 14 HTLV-1 carriers ( 9 females and 5 males) with a mean age of $38 \pm 11$ years (range: 22 to 55 years). They denied a previous history of atopy, and in all of them the SPT was negative for the allergens tested.

\section{Cytokine profile produced by PBMC of atopic and non-atopic HTLV-1 carriers \\ The levels of IFN- $\gamma$, IL-5 and IL-10 in unstimulated cell cultures of patients with} HTLV-1 with $(\mathrm{N}=10)$ and without atopy $(\mathrm{N}$ $=14$ ) are shown in Figure 1. High levels of IFN- $\gamma$ were detected in the supernatants of unstimulated PBMC cultures of HTLV1-infected patients with or without atopy. There was no statistically significant difference between HTLV-1 patients, and in both groups the production of this cytokine was quite variable, with a median value of 1295 $\mathrm{pg} / \mathrm{mL}$, ranging from 34 to $3189 \mathrm{pg} / \mathrm{mL}$ for the atopic group, and a median of $450 \mathrm{pg} /$ $\mathrm{mL}$, ranging from 0 to $3454 \mathrm{pg} / \mathrm{mL}$, for the non-atopic group $(P=0.1$, Mann-Whitney $U$-test). There was no significant difference between the levels of IL-5 in unstimulated supernatants of PBMC from atopic patients with HTLV-1 (median: $0 \mathrm{pg} / \mathrm{mL}$; range: 0 to $189 \mathrm{pg} / \mathrm{mL}$ ) and those from non-atopic patients with HTLV-1 (median: $0 \mathrm{pg} / \mathrm{mL}$; range: 0 to $659 \mathrm{pg} / \mathrm{mL}$ ), $\mathrm{P}=0.7$. IL-10 production did not differ between groups, with a median of $9 \mathrm{pg} / \mathrm{mL}$ (range: 0 to $273 \mathrm{pg} / \mathrm{mL}$ ) for atopic HTLV-1, and $30 \mathrm{pg} / \mathrm{mL}$ (range: 0 to $357 \mathrm{pg} / \mathrm{mL}$ ) for non-atopic HTLV-1, $P=0.2$. These data show no significant difference in the levels of cytokines in unstimulated cultures between the two groups of patients.

The cytokine levels in supernatants of Derp-1-stimulated PBMC are shown in Figure 2. There was a tendency to higher levels of IFN-y in atopic HTLV-1-infected subjects compared to non-atopic HTLV-1-infected controls $(\mathrm{P}=$

Table 1. Demographic data, respiratory clinical manifestations and skin prick test in female patients with concomitant atopy and human T-cell lymphotropic virus type 1 (HTLV-1) infection.

\begin{tabular}{lccccc}
\hline \multirow{2}{*}{ Age (years) } & Rhinitis & Asthma & \multicolumn{3}{c}{ Prick test to aeroallergens $(\mathrm{mm})$} \\
\cline { 3 - 6 } & & & D. pteronyssinus & D. farinae & B. tropicalis \\
\hline 26 & + & - & 3 & 3 & 0 \\
40 & + & - & 3 & 0 & 3 \\
41 & + & - & 4 & 5 & 3 \\
43 & + & + & 4 & 3 & 4 \\
46 & + & + & 4 & 3 & 4 \\
47 & + & - & 3 & 3 & 3 \\
51 & + & - & 10 & 5 & 3 \\
52 & + & - & 4 & 4 & 0 \\
53 & + & - & 3 & 3 & 0 \\
55 & + & + & 3 & 3 & 0 \\
\hline
\end{tabular}

Mean age $( \pm S D)$ of patients was $45 \pm 8$ years.

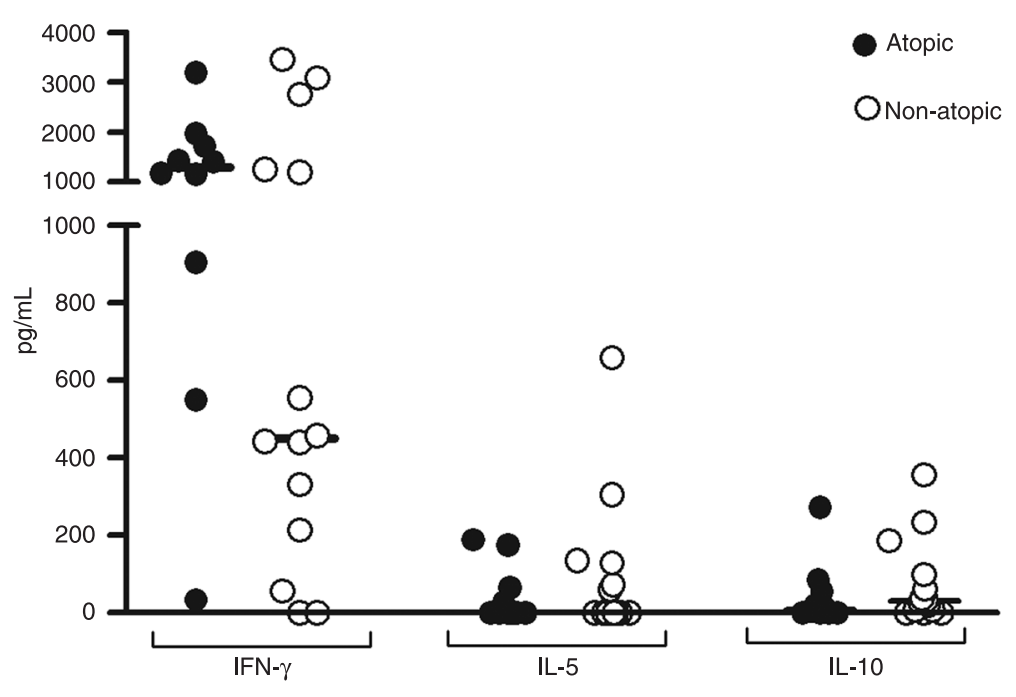

Figure 1. Production of IFN- $\mathrm{y}, \mathrm{IL}-5$ and IL-10 by unstimulated peripheral blood mononuclear cells from atopic $(N=10)$ and non-atopic $(N=14)$ human T-cell lymphotropic virus type 1 (HTLV-1) carriers. The horizontal lines are median. There was no statistical difference between atopic and non-atopic HTLV-1 carriers. 


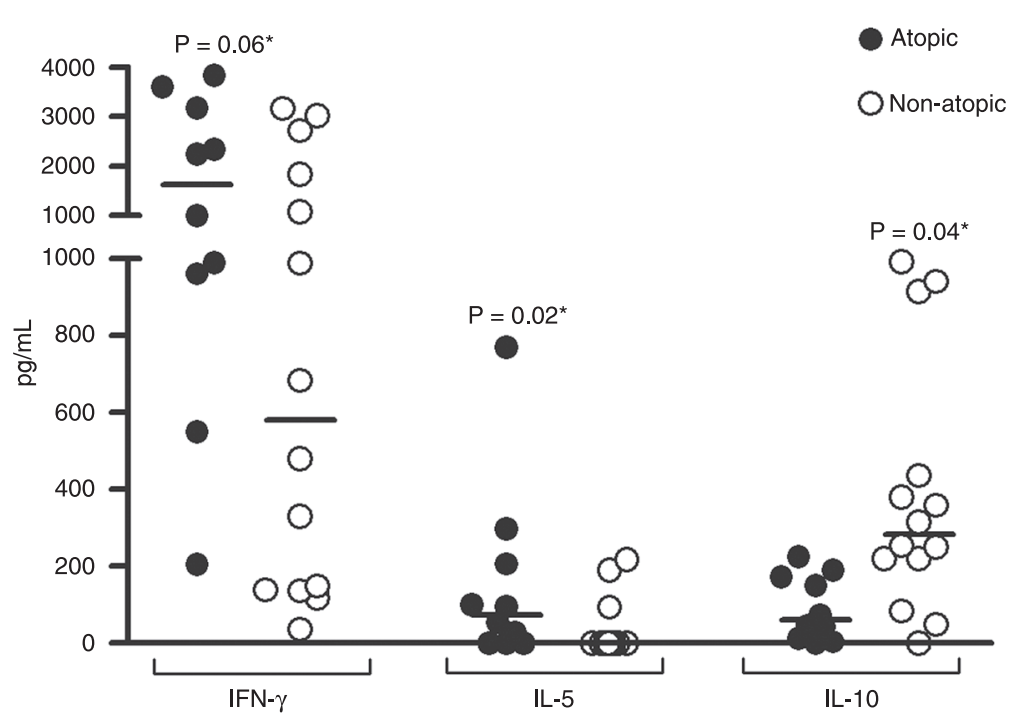

Figure 2. Production of IFN- $\gamma$ IL- 5 and IL-10 by peripheral blood mononuclear cells stimulated with Dermatophagoides pteronyssinus (Derp) 1 antigen from atopic $(\mathrm{N}$ $=10)$ and non-atopic $(\mathrm{N}=14)$ human T-cell lymphotropic virus type 1 (HTLV-1) carriers. The horizontal lines are median. *Mann-Whitney U-test.

0.06). The median value of IFN-Y was $1625 \mathrm{pg} / \mathrm{mL}$ for atopic patients, with values ranging from 206 to $3840 \mathrm{pg} /$ $\mathrm{mL}$, and $582 \mathrm{pg} / \mathrm{mL}$ for non-atopic HTLV-1 carriers, with values ranging from 37 to $3163 \mathrm{pg} / \mathrm{mL}$.

IL-5 levels were significantly higher in Derp-1-stimulated supernatants of PBMC from atopic HTLV-1-infected subjects (median: $74 \mathrm{pg} / \mathrm{mL}$; range: 0 to $770 \mathrm{pg} / \mathrm{mL}$ ) than from non-atopic HTLV-1 carriers (median: 0; range: 0 to $218 \mathrm{pg} /$ $\mathrm{mL}), \mathrm{P}=0.02$.

In contrast, IL-10 levels detected in Derp-1-stimulated cultures from non-atopic HTLV-1 patients were significantly higher compared with HTLV-1-positive patients with atopy $(P=0.004)$. While the median IL-10 produced by PBMC from atopic HTLV-1 carriers was $60 \mathrm{pg} / \mathrm{mL}$ (range: 0 to 226 $\mathrm{pg} / \mathrm{mL}$ ) the median IL-10 levels from non-atopic patients were $284 \mathrm{pg} / \mathrm{mL}$ (range: 0 to $993 \mathrm{pg} / \mathrm{mL}$ ).

\section{Discussion}

In the present study, we showed that the exaggerated type 1 immune response observed in HTLV-1 infection does not prevent the occurrence of asthma and rhinitis. Moreover, the characterization of the immune response in individuals with concomitant atopy and HTLV-1 infection highlights the crucial role of IL-10 in down-modulating the immune response. We documented that IFN-y and IL-5 levels were higher in Derp-1-stimulated cultures of patients with atopy and HTLV-1 infection compared to HTLV-1 carriers with no atopy, and that the concentration of IL-10 was decreased in patients with atopy and HTLV-1 infection.

We have previously published a case report regarding a patient who had severe asthma and HTLV1 infection, but we later showed that the prevalence of atopy based on the positivity of SPT and clinical manifestations was lower in HTLV-1-infected subjects compared to uninfected controls $(17,18)$. Although we cannot rule out the possibility that the exacerbated Th1 immune response observed in HTLV1 infection contributed to the decreased prevalence of atopy determined by the SPT, it is possible that other factors might be involved in reducing the skin test response to aeroallergens in HTLV-1-infected subjects. For instance, the response to the prick test with histamine, used as a positive control, was lower among HTLV-1 carriers (17). Interestingly, other investigators have also found that the test for delayed type hypersensitivity to antigens, a reaction associated with a type $1 \mathrm{immune}$ response, also shows a decreased response by HTLV-1-infected subjects. In such a case, it is more likely that HTLV-1 infection may impair cell migration to the skin, or that the function of the cells responsible for these reactions is down-regulated by unknown mechanisms. The data presented here clearly show that, in patients with HTLV-1 and asthma and rhinitis, Th1 and Th2 responses may not only co-exist, but both of them are enhanced, arguing against the Th1 vs Th2 paradigm in humans. Moreover, all patients studied had positive SPT to at least one allergen, and most of them responded to more than one antigen.

In contrast to the observation made in patients coinfected with HTLV-1 and helminths, in whom HTLV-1 infection decreases type 2 cytokines and $\lg \mathrm{E}$ in the presence of strongyloidiasis and schistosomiasis $(12,13,20)$, and the observation that helminths decrease IFN-Y production in HTLV-1 infection (21), we did not observe these effects in the present study. Although both helminthic infection and asthma are diseases associated with a type 2 immune response, in helminthic infection there is an increase in regulatory T cells and IL-10 production (16). In the present study, IL-10 production was lower in patients with atopy and HTLV-1 infection.

It is known that IL-10 is an essential regulatory cytokine in humans that possibly has an important role in the maintenance of the asymptomatic carrier status in HTLV-1-infected subjects, counterbalancing the pro-inflammatory cytokines IFN- $\gamma$ and TNF- $\alpha$ (22). Previous studies have shown that the production of IL-10 is reduced in ordinary atopic patients (14-16). IL-10 is able to inhibit both type 1 and type 2 immune responses through a suppressive effect on macrophages, T-cell proliferation and pro-inflammatory cytokine production (23-26). Inhibition of T cells by IL-10 has been shown to be related to down-modulation of antigen-presenting cells (27). 
The down-modulation of the immune response mediated by IL-10 in HTLV-1 carriers suggests that this cytokine may directly modulate T-cell activity because T cells from HTLV1 -infected individuals proliferate and produce cytokines independent of accessory cells (28). It is interesting that IL-10 is usually produced at high levels in HTLV-1 carriers (29) and possibly has an impact on the maintenance of asymptomatic carrier status by counterbalancing the proinflammatory cytokines (22). Furthermore, it is known that IL-10 is produced at low levels in asthma patients (14). Thus, the lack of modulation by IL-10 may lead to an increase in both type 1 and type 2 cytokines, allowing the occurrence of atopy in HTLV-1-infected individuals.

\section{References}

1. Castro NM, Rodrigues W Jr, Freitas DM, Muniz A, Oliveira $\mathrm{P}$, Carvalho EM. Urinary symptoms associated with human T-cell lymphotropic virus type I infection: evidence of urinary manifestations in large group of HTLV-I carriers. Urology 2007; 69: 813-818.

2. Caskey MF, Morgan DJ, Porto AF, Giozza SP, Muniz AL, Orge GO, et al. Clinical manifestations associated with HTLV type I infection: a cross-sectional study. AIDS Res Hum Retroviruses 2007; 23: 365-371.

3. Giozza SP, Santos SB, Martinelli M, Porto MA, Muniz AL, Carvalho EM. [Salivary and lacrymal gland disorders and HTLV-1 infection]. Rev Stomatol Chir Maxillofac 2008; 109: 153-157.

4. Neva FA, Murphy EL, Gam A, Hanchard B, Figueroa JP, Blattner WA. Antibodies to Strongyloides stercoralis in healthy Jamaican carriers of HTLV-1. N Engl J Med 1989; 320: 252-253.

5. Porto MA, Muniz A, Oliveira JJ, Carvalho EM. [Clinical and immunological consequences of the association between HTLV-1 and strongyloidiasis]. Rev Soc Bras Med Trop 2002; 35: 641-649.

6. Marinho J, Galvao-Castro B, Rodrigues LC, Barreto ML. Increased risk of tuberculosis with human T-lymphotropic virus-1 infection: a case-control study. J Acquir Immune Defic Syndr 2005; 40: 625-628.

7. Pedral-Sampaio DB, Martins NE, Pedrosa C, Brites C, Duarte M, Harrington W Jr. Co-infection of tuberculosis and HIV/HTLV retroviruses: frequency and prognosis among patients admitted in a Brazilian hospital. Braz $\mathrm{J}$ Infect Dis 1997; 1: 31-35.

8. Santos SB, Porto AF, Muniz AL, Jesus AR, Carvalho EM. Clinical and immunological consequences of human $T$ cell leukemia virus type-I and Schistosoma mansoni coinfection. Mem Inst Oswaldo Cruz 2004; 99: 121-126.

9. Goncalves DU, Guedes AC, Proietti AB, Martins ML, Proietti FA, Lambertucci JR. Dermatologic lesions in asymptomatic blood donors seropositive for human $T$ cell lymphotropic virus type-1. Am J Trop Med Hyg 2003; 68: 562-565.

10. Santos SB, Porto AF, Muniz AL, Luna T, Nascimento MC, Guerreiro JB, et al. Modulation of T cell responses in HTLV1 carriers and in patients with myelopathy associated with HTLV-1. Neuroimmunomodulation 2006; 13: 145-151.
The present study shows that atopy may occur in a typical Th1 environment. This is associated with a reduction in IL-10 levels, an important immunoregulatory cytokine that plays a major role in modulating type 1 and type 2 immune responses.

\section{Acknowledgments}

We thank Elbe Silva and Lucia Reis, Serviço de Imunologia, Hospital Universitário Prof. Edgard Santos, Universidade Federal da Bahia, for technical and secretary assistance in preparing this manuscript, respectively. Research supported by CNPq.

11. Porto AF, Neva FA, Bittencourt H, Lisboa W, Thompson R, Alcantara L, et al. HTLV-1 decreases Th2 type of immune response in patients with strongyloidiasis. Parasite Immunol 2001; 23: 503-507.

12. Porto AF, Santos SB, Alcantara L, Guerreiro JB, Passos J, Gonzalez T, et al. HTLV-1 modifies the clinical and immunological response to schistosomiasis. Clin Exp Immunol 2004; 137: 424-429.

13. Neva FA, Filho JO, Gam AA, Thompson R, Freitas V, Melo $A$, et al. Interferon-gamma and interleukin-4 responses in relation to serum IgE levels in persons infected with human T Iymphotropic virus type I and Strongyloides stercoralis. $J$ Infect Dis 1998; 178: 1856-1859.

14. Takanashi S, Hasegawa Y, Kanehira Y, Yamamoto K, Fujimoto K, Satoh K, et al. Interleukin-10 level in sputum is reduced in bronchial asthma, COPD and in smokers. Eur Respir J 1999; 14: 309-314.

15. van der Velden V, Laan MP, Baert MR, de Waal MR, Neijens HJ, Savelkoul HF. Selective development of a strong Th2 cytokine profile in high-risk children who develop atopy: risk factors and regulatory role of IFN-gamma, IL-4 and IL-10. Clin Exp Allergy 2001; 31: 997-1006.

16. Araujo MI, Hoppe B, Medeiros M Jr, Alcantara L, Almeida MC, Schriefer A, et al. Impaired T helper 2 response to aeroallergen in helminth-infected patients with asthma. $J$ Infect Dis 2004; 190: 1797-1803.

17. Souza-Machado A, Galvao TS, Porto A, Figueiredo J, Cruz AA. Skin reactivity to aeroallergens is reduced in human T-lymphotropic virus type l-infected healthy blood-donors (asymptomatic carriers). Allergy 2005; 60: 379-384.

18. Souza-Machado A, Cruz AA, Galvao TS, Muniz A, Porto A, Braga $S$, et al. Paradoxical coexistence of atopic asthma and human T-lymphotropic virus type I (HTLV-I) infection: a case report. J Investig Allergol Clin Immunol 2004; 14: 348-351.

19. Asher MI, Weiland SK. The International Study of Asthma and Allergies in Childhood (ISAAC). ISAAC Steering Committee. Clin Exp Allergy 1998; 28 (Suppl 5): 52-66.

20. Porto AF, Oliveira FJ, Neva FA, Orge G, Alcantara L, Gam A, et al. Influence of human T-cell lymphocytotropic virus type 1 infection on serologic and skin tests for strongyloidiasis. Am J Trop Med Hyg 2001; 65: 610-613.

21. Porto MA, Alcantara LM, Leal M, Castro N, Carvalho EM. 
Atypical clinical presentation of strongyloidiasis in a patient co-infected with human T cell lymphotrophic virus type I. Am J Trop Med Hyg 2005; 72: 124-125.

22. Brito-Melo GE, Peruhype-Magalhaes V, Teixeira-Carvalho A, Barbosa-Stancioli EF, Carneiro-Proietti AB, Catalan-Soares $B$, et al. IL-10 produced by CD4+ and CD8+ T cells emerge as a putative immunoregulatory mechanism to counterbalance the monocyte-derived TNF-alpha and guarantee asymptomatic clinical status during chronic HTLV-I infection. Clin Exp Immunol 2007; 147: 35-44.

23. Del Prete G, de Carli M, Almerigogna F, Giudizi MG, Biagiotti R, Romagnani S. Human IL-10 is produced by both type 1 helper (Th1) and type 2 helper (Th2) T cell clones and inhibits their antigen-specific proliferation and cytokine production. J Immunol 1993; 150: 353-360.

24. Araújo M, Carvalho EM. Human schistosomiasis decreases immune response to allergens and clinical manifestations of asthma. In: Capron M, Trottein F (Editors), Parasites and allergy. Basel: Karger; 2006. p 29-44.

25. Ponte EV, Rizzo JA, Cruz AA. Interrelationship among asthma, atopy, and helminth infections. J Bras Pneumol 2007; 33: 335-342.

26. Ponte EV, Lima F, Araujo MI, Oliveira RR, Cardoso LS, Cruz AA. Skin test reactivity and Der p-induced interleukin 10 production in patients with asthma or rhinitis infected with Ascaris. Ann Allergy Asthma Immunol 2006; 96: 713-718.

27. Moore KW, de Waal MR, Coffman RL, O'Garra A. Interleukin-10 and the interleukin-10 receptor. Annu Rev Immunol 2001; 19: 683-765.

28. Hollsberg P. Mechanisms of T-cell activation by human T-cell lymphotropic virus type I. Microbiol Mol Biol Rev 1999; 63: 308-333.

29. Carvalho EM, Bacellar O, Porto AF, Braga S, GalvaoCastro B, Neva F. Cytokine profile and immunomodulation in asymptomatic human T-lymphotropic virus type 1-infected blood donors. J Acquir Immune Defic Syndr 2001; 27: 1-6. 